\title{
Exploring the Dimensions of Electronic Government Service Quality
}

\author{
Dr. Taiseera Hazeem Al Balushi \\ Assistant Professor, Department of Information Systems, \\ College of Economics and Political Science \\ Sultan Qaboos University \\ Muscat, Oman \\ taisira@squ.edu.om
}

\author{
Dr. Saqib Ali \\ Associate Professor, Department of Information Systems, \\ College of Economics and Political Science \\ Sultan Qaboos University \\ Muscat, Oman \\ saqib@squ.edu.om
}

\begin{abstract}
Information and communication technology is progressively evolving around the world. Organizations and providers of online services, have to keep up with technological advancements when providing services and meet the redoubling expectations of its customers. At a global level there is wider adoption of e-government, a term coined in the recent past to describe the methodology that implements technology efficiently with quality of service for the general public's administration in a government setting. This research proposes a scale for measuring quality dimension in setting of e-government by an extensive review of literature from last 3 decades and by revising the SERVQUAL scale. The proposed scale is based on 25 items and six quality dimensions namely: reliability, responsiveness, ease of uselusability, website design\content, and security $\backslash$ privacy. This research is fruitful for organizations to assess, measure, and improve the quality of service concerning the e-government services they offer.
\end{abstract}

Keywords-component; Service quality, E-service quality, Egovernment service quality, Determinant of quality, measurements of quality, Factors of E-service quality, Measurement of quality

\section{INTRODUCTION}

Although not marked curtly, technology and its advancements drive the societies and communities of the modern world. To keep up with the present age communication technology that provides prompt services, reinforcing technology needs to be implementing in the society. To this end, e-government, was introduced in the recent years, a terms that describes how to forte technology to boost the efficiency and quality of public administration in a government setting.

A prime challenge for the growing world is to develop egovernment settings with quality of services. The eminent electronic government relies on its quality and usage [1]. Quality plays a leading role in maintaining trust between customer/citizen and government. The purpose of egovernment in general, is to make information available online to citizenslusers and allow them to communicate with the system by exchanging information. One of the most critical concerns of E-governments are to prioritize and invest in those quality factors that are of greater interest to citizens [2]. The governments need to improve the information communication technology for the assurance of reliable communication which fulfill the high quality service expectation of citizens/client[3].

(DOI Reference No:10.18293/SEKE2016-061)
The purpose of this research is to identify key elements of eservice quality dimensions that play an influential role in quality of e-services in setting of e-government. The basic purpose of identifying dimensions is to maintain the quality of service which meets the customer/citizen satisfaction level. Quality is a steering tool without which it is difficult for the government to provide effective projects that fulfills the need of users/citizens. The next session of the paper discuss the ways how the research has been conducted, the literature review of the e-service quality and e-government service quality is discussed, and on the basis of the studies the dimensions of the proposed instrument is presented.

\section{METHOD OF STUDY}

The purpose of the review is to identify the current issues that help the practitioners and the academicians to get the up to date information about the recent and relevant information about the current trends of e-government.

To conduct an extensive literature review based on systematic process with good clarity, completeness and conciseness, the systematic literature review (SLRs) research methodology is adopted in this study. Two types of SLR are conventional systematic literature review and Mapping Studies[4]. In Conventional Systematic Literature Review collection of literature is based on a specific research question and Mapping Studies is a process that finds and classifies the primary studies in a specific topic area. In this paper, Mapping Studies methodology is adopted for the sake of conducting systematic literature review since, in the context of this paper, primary studies are the key sources to find out the effective quality dimensions in domain of e-government.

\section{A. Data Extraction}

The search process involves the reading of articles from world known journals. The sources of studies are from the different electronic data base that includes, IEEE Xplore, ACM Digital Library, Science Direct, Springer Link, Engineering Link, Google scholar, Research Gate, Scopus. Different electronic resources are utilized that includes Asian Social sciences Journal Canada, International Journal for innovation education and research and journal of service marketing, Emerald etc. During search of the content it is ensure that no important data/ information is missing. The research involves in finding 
the key dimensions for E government services. The key words used during the search includes, E-government, E-services, Dimension for e-services, dimensions for E-governemnt, Eservices quality models, E-government Quality models. During the search, 195 papers were found from different journals and proceedings of conferences, out of which 70 were effective for further reading.

The universities of different countries are doing research on $\mathrm{E}$ services / E-govt services. In general the universities from United States are in the leading position. United states stands as the pioneers in providing test bench for studies of service quality by providing a test model SERVQUAL and it has been adopted by numerous authors as reference for their studies [5]. The universities of Greece, and Malaysia also provides different scales to evaluate e government quality named as Egovqual [6]. A multiple item scale for assessing egovernment services quality tested by the online survey for different demographic values[7]. United Kingdom is also playing a vital role where also number of universities studying the e-services and e-government services dimensions. The University of Bath involved in research over data triangulation and web quality matrices[8]. In Asia, China is in the leading position as there also many universities involve in this area. Where, University of shanghai studied user satisfaction by assessment of E-govt service quality. University of Calicut and University of Kerala performed a comparative analysis of E-banking by using serv-qual model in public and private sector banks [9]. The universities of GCC region are also studying E govt service quality, but they are lacking a part. King Abdul Aziz university of KAE theoretically studied the satisfaction of end user by studying dimensions[10].

Sultan Qaboos University, Oman in 2015 analyzed trends of the quality dimensions in the context of evaluating egovernment services [11]. Another research at Sultan Qaboos University in 2013 found that the Royal Oman Police were the most prominent department that had adopted E-services. The research involves focused group interviews and also a survey whose results based on around 800 questionnaires. The research was the first step for evaluating the E-government services in Oman but lacks on studying E-government services in different cities with different demographic values[12].

\section{LITERATURE REVIEW}

\section{A. Service Quality}

The scope of research reveals that studying services quality in different domains is growing rapidly. These domain can mainly divided in three parts, service quality, E-service quality, E-government service quality. Method of quantifying service quality and the dimensions of service quality has become considerable area in promoting e-government. A SERVQUAL model presented in mid 1980s is considered as the bench mark for researchers. The concept of service quality is new to researchers and not specific to any class [13].

SERVQUAL is a well-known model that represent ten service quality dimensions for measurement of quality: responsiveness, competence, access, courtesy, communicating, creditability, security, understanding/ knowing the customer, and tangible[5]. Revised SERVQUAL model simplifies into five key dimensions which are reliability, assurance, tangibles, empathy, and responsiveness. This is a traditional model that is adopted by researchers in different domain as a reference frame in their studies. Parsuraman (1988) presented a 22 items based a comprehensive SERVQUAL model for assessing service quality in service and retail organizations[14].

\section{B. E-Service Quality}

Maintaining the quality of e-service is becoming principal for providing satisfactory services to the citizens/users. For measuring quality various researchers proposed various dimensions in different domains and context of applications. SITEQUAL was proposed to measure the perceived quality of the internet shopping site[15], Madhu \& Madhu (2002) proposed 15 dimensions of e-services quality; performance, features, structure, aesthetics, reliability, storage capacity, Service ability, security and system integrity, trust, responsiveness, productive services, Web store policy, reputation, assurance and empathy[18], Wolfinbarger (2003) in united states presented a model ETAILQ for online retailing by identifying four key quality dimensions website design, fulfillment/reliability, privacy/security and customer services[19]. Santouridis (2012) examined the applicability of E-S-Qual and identified four dimensions: efficiency, fulfillment, system availability and privacy[30]. Janita (2013) explored service quality dimensions in B2B e-marketplaces and identified four dimensions: reliability, privacy, utility or the information, valued-add service [31]. Achchuthan (2014) in Sri Lanka developed an empirical model of service quality in terms of electricity services. The following dimensions, Tangibility, Empathy, Responsiveness, Reliability and Assurance are being utilized to conduct a study, In a result, 300 usable responses are collected from end users In the context of e-government, quality dimensions of e-service become important ingredients to measure the satisfaction level of users/citizens. In the last decade, many researchers conducted various researches to determine effective quality dimensions and measuring methods that influence the quality of e-services in e-government [6, 36-49]

\section{Service Quality Dimensions for E-Government}

Advancements in the information technology forced governments to adopt changes and provide e-services in government domains. In a larger context, e-services in egovernment require more satisfaction of end user in term of services quality. The satisfaction level of end user can only assess by measurement of e-service quality dimensions. Abhichandani (2005) from united states firstly measure the e service quality dimension on government web sites. A total of 416 respondents of Los Angeles and Minneapolis evaluated the three different dimensions utility efficiency and customization. On the basis of the results a future frame has also suggested for other authors[37]. In 2006, Ibrahim conducted a survey by using e-Sq approach to study the e 
service quality of UK banks. The study based on the 135 samples from UK banking customers to evaluate the perceived service quality on the basis seven dimensions, convenience/accuracy, accessibility/reliability, good queue management, personalization, friendly\responsiveness, customer service, and targeted customer service[50].

Arathy (2015) used SERVQUAL model to perform a comparative analysis of e-Banking in India. The dimensions used to evaluate the reliability, responsiveness, competence, access, communication, credibility, security and tangibility. The study suggests that service quality dimensions has strong impact on customer satisfaction[55]. A study is conducted in India where different Brand perception, responsiveness, merchandising, reliability, trust/security, website design and easy to use were evaluated and found that they are the important factors for customer satisfaction[56].

\section{PROPOSED INSTRUMENT}

The proposed scale has six quality dimensions and 25-items. The scale is based on SERVQUAL scale and literature review from the last 3 decades. The table below shows that the dimensions of the proposed scale are frequently used by different authors in their studies.

After analysis of data presented in Table 1, reliability is the most important dimension which has been discussed by different authors in their studies. Security/privacy is also the major concern for authors whose frequency dramatically increases in the last five year. Web Site design/content is also an important dimension, that's why it is also the part of discussion of different authors. The frequency of website design and content significantly rise in between 2006 and 2010. The frequency of ease of use/ usability shows that it has been vastly studied by different authors in last decade. The dimensions of proposed scale are website design/content (6Items), efficiency (3-Items), security/privacy (5-Items), ease of usel usability (6-Items), responsiveness (5-Items), and reliability (3-Items).

TABLE I. PROPOSED INSTRUMENT

\begin{tabular}{|l|l|}
\hline Reliability & $\begin{array}{l}\text { Reliability is a commitment to ensure reliable, } \\
\text { accurate and on-time services are provided by the e- } \\
\text { government websites to its citizenslusers. }\end{array}$ \\
\hline Responsiveness & $\begin{array}{l}\text { Responsiveness is a commitment to ensure } \\
\text { availability of online e-government services and to } \\
\text { help customers or citizens by providing prompt } \\
\text { services when using the e-government websites. }\end{array}$ \\
\hline $\begin{array}{l}\text { Ease } \\
\text { UselUsability of }\end{array}$ & $\begin{array}{l}\text { Ease of use represents having a friendly interface or } \\
\text { environment between customer/citizens and } \\
\text { government by owning a website that is user- } \\
\text { friendly and accessible by anyone from anywhere. }\end{array}$ \\
\hline Content & $\begin{array}{l}\text { Website Design/content refers to the functionality of } \\
\text { website in terms of efficiency, visual appeal and } \\
\text { useful content in an e-government websites. }\end{array}$ \\
\hline Efficiency & $\begin{array}{l}\text { Efficiency in an E-government website ensures that } \\
\text { the services are up-to-date, efficient and satisfies the } \\
\text { requirements of both customers/citizen and the } \\
\text { government. }\end{array}$ \\
\hline Security/Privacy & $\begin{array}{l}\text { Security/privacy represents a trust which assures } \\
\text { that the information of citizens/customers is safe, } \\
\text { secure and safe from infringement in e-government } \\
\text { websites. }\end{array}$ \\
\hline
\end{tabular}

\section{DISCUSSION \& CONCLUSION}

The objective of this research is to investigate the quality dimension for measuring e-quality service so as to provide quality service to the users/citizens in domain of egovernment. Through investigation of previous literature regarding quality dimensions and models, this research proposed a 25-items six dimensions quality scale in the context of e-government service quality which is based on the revised SERVQUAL. The proposed six dimensions are: reliability, responsiveness, ease of use/usability, website designlcontent, and security/ privacy. The proposed scale is valuable to countermeasure the factors which are influencing the quality of service in domain of e-government services.

\section{ACKNOWLEDGMENT}

The Research leading to these results has received Research Project Grant Funding from the Sultan Qaboos University of the Sultanate of Oman, Research Grant Agreement No [SR/EPS/INFS/14/01].

\section{REFERENCES}

[1] S. F. H. Zaidi, et al., "Development and Validation of a Framework for Assessing the Performance and Trust in E-Government Service," International Journal of Applied Information Systems (IJAIS), vol. 17, 2014.

[2] T. H. AlBalushi and S. Ali, "Evaluation of the quality of Egovernment services: Quality trend analysis," in Information and Communication Technology Research (ICTRC), 2015 International Conference on, 2015, pp. 226-229.

[3] A. Manoharan, "A three dimensional assessment of U.S. county egovernment," State and Local Government Review vol. 45, pp. 153-162, 2013.

[4] B. Kitchenham, et al., "Systematic literature reviews in software engineering - A tertiary study," Information and Software Technolog, vol. 52, pp. 792-805, 2010.

[5] A. Parasuraman, et al., "A Conceptual Model of Service Quality and Its Implications for Future Research," The Journal of Marketing, vol. Vol. 49, No. 41985.

[6] M. Alanezi, et al., "A proposed instrument dimensions for measuring e-government service quality," International Journal of $u$-and e-Service, Science and Technology Service, vol. 3, pp. 1-18, 2010.

[7] X. Papadomichelaki and G. Mentzas, "E-GovQual: A multipleitem scale for assessing e-government service quality," Journal of Government Information Quartley, vol. 29, pp. 98-109, 2012.

[8] S. J. Barnes and R. T. Vidgen, "Data triangulation and web quality metrics: A case study in e-government," Journal of Information \& Management, vol. 43, pp. 767-777, 2006.

[9] C. Arathy and B. V. Pillai, "Customer statisfaction on e-banking services in public and private sector banks: a coparative analysis using SERVQUAL model," International Journal of Business and Administration Research Review (IJBARR), vol. 2, pp. 106-111, 2015.

[10] F. Al- Farsi and A. Basahel, "The sequence of electronic service quality on customer satisfaction: theoretical study," International Journal for Innovation Education and Research, vol. 2, pp. 10-24, 2014.

[11] T. H. AlBalushi and S. Ali, "Quality Dimensions Trend Analysis in the Context of Evaluating E-government Services," Research Journal of Applied Sciences, Engineering and Technology, vol. 11, pp. 315-324, 2015.

[12] S. K. Sharma, et al., "Exploring Quality of E-Government Services in Oman," Education, Business and Society: Contemporary Middle Eastern vol. 6, pp. 87-100, 2013. 
[13] A. Parasuraman, et al., "A conceptual model of service quality and its implications for future research," The Journal of Marketing, vol. 49, pp. 41-50, 1985.

[14] A. Parasuraman, et al., "SERVQUAL: a multiple-item scale for measuring consumer perception of service quality," Journal of Retailing, vol. 64, pp. PP. 12-40, 1988.

[15] B. Yoo and N. Donthu, "Developing a sale to measure the perceived quality of an Internet shopping site (SITEQUAL)," Quarterly Journal of Electronic Commerce, vol. 2, pp. 31-47, 2001.

[16] E. T. Loiacono, et al., "WEBQUAL: A measure of website quality," Marketing Educators Conference: Marketing Theory and Applications, vol. 13, pp. 432-437, 2002.

[17] E. T. Loiacono, et al., "WebQual Revisted: Predicting the intent to reuse a website," presented at the Eighth Americas Conference on Information Systems, 2002.

[18] C. N. Madu and A. Madu, "Dimensions of e-quality," International Journal of Quality and reliability Management, vol. 19, pp. 246258, 2002

[19] M. Wolfinbarger and M. Gilly, "eTailQ: dimensionalizing, measuring and predictingetail quality," Journal of Retailing, vol. 79, pp. 183-198, 2003.

[20] S. Cai and M. Jun, "Internet users perceptions of on-line service quality: a comparison of online buyers and information searchers," Managing Service Quality: An International Journal, vol. 13, pp. $504-519,2003$.

[21] M. Long and C. McMellon, "Exploring the determinants of retail service quality on the Internet," Journal of Services Marketing, vol. 18 , pp. $78-90,2004$

[22] A. Parasuraman, et al., "E-S-QUAL a multiple-item scale for assessing electronic service quality," Journal of Service Research, vol. 7, pp. 213-233, 2005.

[23] A. Caruana and M. T. Ewing, "The psychometric properties of eTail quality," International Marketing Review, vol. 23, pp. 353 370, 2006.

[24] M. Fassnacht and I. Koese, "Quality of electronic services; conceptualizing and testing a hierarchical model," Journal of Service Research, vol. 9, pp. 19-37, 2006.

[25] K. Heinonen, "The role of customer participation in creating eservice value," presented at the Conference Proceedings of frontier of e-business research, 2006.

[26] H. H. Bauer, et al., "eTransQual: A transaction process-based approach for capturing service quality in online shopping," Journal of Business Research, vol. 59, pp. 866-875, 2006.

[27] E. Cristobal, et al., "Perceived e- service quality (PeSQ)," Managing Service Quality: An International Journal, vol. 17, pp. $317-340,2007$.

[28] C. Sohn and S. Tadisina, "Development of e-service quality measure for internet-based financial institutions," Total Quality Management, vol. 19, pp. 903-918, 2008.

[29] S. Akinci, et al., "Re-assessment of E-S-Qual and E-RecS-Qual in a pure service setting," Journal of Business Research, vol. 63, pp. 232-240, 2010.

[30] L. Santouridis, et al., "Using E-S-QUAL to measure internet service quality of e- commerce websites in Greece," International Journal of Quality and Service Sciences, vol. 4, pp. 86-98, 2012.

[31] M. S. Janita and F. J. Miranda, "Exploring service quality dimensions in B2B e-marketplaces," Journal of Electronic Commerce Research, vol. 14, pp. 363-386, 2013.

[32] Y. Li, "Main factors affecting the online service satisfaction an empirical study in china," International Journal of Smart Home, vol. 8, pp. 131-144, 2014.

[33] S. Hussain, "Measuring quality of electronic service (e- service) in banking," International Journal of Engineering Research and Applications, vol. 4, pp. 350-359, 2014.

[34] S. Achchuthan, et al., "Service quality dimension of electricity services: evidence from electricity board in sri lanka," Asian Social Science, vol. 10, pp. 194-203, 2014.

[35] H. Muhammad and G. I. Tanko, "Antecedents of e-service, quality, perceived value and moderating effect of esatisfaction with e-loyalty in airline industries" International Journal of Economics, Commerce and Managementvol. III,,
May,2015 2015.[36] A. Abanumy, et al., "E-government website accessibility: In-depth evaluation of Saudi Arabia and Oman," Electronic Journal of e-Government, vol. 3, pp. 99-106, 2005.

[37] T. Abhichandani, et al., "EGOVSAT: Toward a robust measure of e-government service satisfaction in transportation," in International Conference on e-Government, Ottawa, Canada, 2005, pp. 1-12.

[38] K. Al-Gharbi and A. Al-Kindi, "E-government initiative in the sultanate of oman: the case of ubar," in Knowledge and Technology Adoption, Diffusion, and Transfer: International Perspective, A. H. S. Zolait, Ed., ed: IRMA International, 2012, pp. 73-77.

[39] M. Alanezi, et al., "E- government service quality: a qualitative evaluation in the case of Saudi Arabia," vol. The Electronic Journal on Information Systems in Developing Countries pp. 1-20, 2012.

[40] D. Bhattacharya, et al., "E-service quality model for Indian government portals: citizens perspective," Journal of enterprise information management, vol. 25, pp. 246-271, 2012.

[41] N. M. Hein, "A study on evaluation of e-government service quality," International Journal of Social, Management, Economics and Bussiness Engineering vol. 8, pp. 16-19, 2014.

[42] G. Kaisara and S. Pather, "The e-government evaluation challengeA South African batho pele-aligned service," Government Information Quarterly, vol. 28, pp. 211-221 2011.

[43] J.-S. C. Lin and P.-L. Hsieh, "Assessing the self-service technology encounters: development and validation of SSTQUAL scale " Journal of Retailing, vol. 87, pp. 194-206, 2011.

[44] A. M.Al Khouri, "eGovenment strategies the case of the United Arab Emirates (UAE)," European Journal of ePractice, vol. September 2012, pp. 126-150, 2012.

[45] B. Magoutas and G. Mentzas, "SALT: A semantic adaptive framework for monitoring citizen satisfaction from e-government services," Expert Systems with Applications, vol. 37, pp. 42924300, 2010.

[46] I. H. Osman, et al., "COBRA framework to evaluate e-government services: A citizen-centric perspective " in tGov Workshop, Brunel University, West London, 2011.

[47] M. Rehman, et al., "Factors influencing e-government adoption in Pakistan," Transforming Government: People, Process and Policy, vol. 6 , pp. 258 - 282, 2012.

[48] M. A. Shareef, et al., "An empirical investigation of electronic government service quality: from the Demand-side stakeholder perceptive," Total Quality management, vol. 26, pp. 339-354, 2013.

[49] Y. M. Sheibani and E. Fariborzi, "E- government service in Iran: looking at citizen satisfaction," presented at the 2011 International Conference on Communication Engineering and Networks IPCSIT, Singapore, 2011.

[50] E. E. Ibrahim, et al., "Customer perception of electronic service delivery in the UK retail banking sector," International Journal of Bank Marketing, vol. 24, pp. 475-493, 2006.

[51] S. Rotchanakitumnuai, "Measuring e-government service value with the E-GOVSQUAL-RISK model," Business Process Management Journal, vol. 14, pp. 724 - 737, 2008.

[52] D. X. Ding, et al., "e-SELFQUAL: A scale for measuring online self-service quality," Journal of Business Research, vol. 64, pp. 508-515, 2011.

[53] E. T. Loiacono and S. Deshpande "WebQual and its relevance to users with visual disabilities," presented at the HCIB/HCII Switzerland, 2014.

[54] M. Stiglingh, "A measuring instrument to evaluate e-service quality in revenue authority setting " Public relations review, vol. 40, pp. 216-22, 2014.

[55] Arathy and B. V. Pillai, "Customer satisfaction on e banking services in public and private sector banks - a comparative analysis using servqual model," IJBARR, vol. 2, Jan- March, 20152015.

[56] D. V. Akshya Singh, Vandana Bharti, "An Examination of the Relationship between Service Quality Dimensions, Overall Internet Banking Service Quality and Customer Satisfaction," International Journal of scientific research and management, vol. 3, pp. 19781988, 2015. 